\title{
Business Model Innovation and Value-creation: The Triadic Way
}

\author{
Tor W. Andreassen, Professor * \\ Director Center for Service Innovation \\ NHH Norwegian School of Economics \\ Email: Tor.W.Andreassen@nhh.no \\ Line Lervik-Olsen, Professor \\ BI - Norwegian Business School \\ Email: line.lervik-olsen@bi.no \\ Hannah Snyder, Assistant professor \\ Bi - Norwegian Business School \\ Email: hannah.snyder@bi.no
}
Allard C.R. van Riel, Professor of Service Innovation Management
Department of Marketing and Strategy
Faculty of Business Economics
Hasselt University
Hasselt, Belgium
Email: allard.vanriel@uhasselt.be
Jillian C. Sweeney, Professor, Business School, The University of Western Australia, Perth, WA 6009, Australia.
Email: jill.sweeney@uwa.edu.au
Yves Van Vaerenbergh, Associate Professor
Department of Marketing
KU Leuven
Brussels, Belgium
Email: yves.vanvaerenbergh@kuleuven.be

Forthcoming in Journal of Service Management

* Corresponding author.

\section{Acknowledgments}

Authors are listed randomly reflecting equal contribution. We thank the editor of Journal of Service Management and Prof Janet McColl-Kennedy for taking the initiative and hosting the Brisbane Thought leader conference that gave birth to this research. We also want to thank two anonymous reviewers for their valuable comments. 


\title{
Business Model Innovation and Value-creation: The Triadic Way
}

\author{
Abstract \\ Purpose - Building on the Multi-divisional business model (M-model), the purpose of this paper \\ is to develop a better understanding of triadic business models - T-models - and how they create \\ value for their three categories of stakeholders, i.e., the suppliers, the platform firm, and the \\ buyers. The research question that guides the present study is twofold: How is value created \\ individually and collectively in triadic business models and what might challenge their \\ sustainability?
}

Design/methodology/approach - Anchored in extant literature and a process of conceptual modelling with empirical examples from Uber, a new business model archetype was developed for two-sided markets mediated by a middleman.

Findings - The paper identifies, illustrates and discusses the ways in which value is created in sustainable T-models. First, value is created from a number of sources, not only from lower transaction costs. Second, it is proposed that it is not about a choice of either M-model or Tmodel but rather a continuum. Toward 2050, technology in general and Blockchain specifically may for some transactions or services, eliminate the need for middlemen. The main conclusion is that despite this development, there will, for most organizations, be elements of the M-model in all or most T-model businesses. In short: middlemen will have elements of the M-model embedded in the T-model when co creating value with buyers and sellers.

Originality/Value - While two-sided T-models are not new to the business area, surprisingly no papers have systematically investigated, illustrated, and discussed how value is created among and between the three stakeholder categories of the T-model. With this insight, more sustainable T-models can be created.

Keywords: Triadic business models, value creation, platform, two-sided market, sustainability, innovation, sharing economy

Paper type: Conceptual 


\section{Introduction}

According to Coase (1937), firms exist as an alternative to the market-price mechanism when it is more efficient to produce in a non-market environment. Nobel laureate Coase' reasoning was later popularized by Williamson in his Transaction Cost Economics (1981). Eighty years after Coase's seminal work, it can be observed that value is created and co-created in large hierarchical service and manufacturing organizations employing several thousands of employees, such as Walmart (2,3M employees) and Volkswagen (600K employees). These robust institutions make use of what is often called multidivisional business models ${ }^{1}$, or M-models for short. The authors predict that by 2050 transactions will to a large extent be conducted in a way highly consistent with Coase's (1937) market exchange logic, - according to which individual buyers and sellers, may interact directly - via high-tech platforms. What is currently taking place in the sharing, collaborative, and access economy, is just the beginning. By 2050, supported by technological innovations such as Blockchain, there will be an increasing amount of peer-to-peer transactions taking place without middlemen or mediating organizations.

These fundamental changes will require organizations to rethink their current business model in order to sustain competitive advantage. The business model concept has become highly relevant for firms, as it allows them to identify opportunities for improvement and innovation in the way they conduct their business. A business model can be defined as "the design or architecture of the value creation, delivery, and capture mechanisms (a business) employs" (Teece, 2010, p. 172), or as "a bundle of specific activities and activity systems conducted to satisfy the perceived needs of the market, along with the specification of which parties (a

\footnotetext{
${ }^{1}$ Multi-divisional business model $=$ one parent company that consists of a number of different divisions operating separate businesses. Legally, the parent company owns all of the divisions, but the parent company gives the divisions significant autonomy, which allows them to act independently.
} 
company or its partners) conduct which activities, and how these activities are linked to each other" (Foss and Saebi, 2018 p.13). The value of using such a framework is that it highlights differences and similarities in the way organizations create value between, for example, British Airways and Ryanair.

Recently, new technologies have spurred the development and exponential growth of what can be called the triadic business model (hereafter: T-model), employed by companies such as Alibaba, Uber, TaskRabbit, and Craigslist. In its basic form, the T-model aims at creating value by facilitating interactions and transactions (via a platform) among two or more (groups of) actors, usually buyers and suppliers of a product, service or other resource (e.g., data). In the literature, the T-model is often referred to as representing two-sided markets (see, for example, Hagiu and Wright, 2015). Simply put, suppliers provide assets (e.g., accommodation or tools when not in use) or labor (e.g., free time) for buyers to use, potentially in exchange for a fee or another resource. The platform company offers a value proposition to buyers based on the availability of suppliers' assets or time. The platform performs the role of a new form of middleman, and directly connects buyers and suppliers (Marshall et al., 2016a; Benoit et al., 2017; Gatautis, 2017) thereby reducing both search and information costs and the bargaining costs of interacting (Coase, 1937). The middleman role could comprise identifying, selecting, connecting, equipping or pairing actors, or centralizing and standardizing service flows (Perren and Kozinets, 2018).

Despite the promising prospects of the triadic business model, and its abundance in the market place, there has been great variability in the implementations and success of the model with obvious risks for the supplier, the customer and society. Recently, a number of T-model based companies have experienced a quick rise and fall and have been struggling with sustaining 
their business over time (Perren and Kozinets, 2018; Marshall et al., 2016b). Questions have risen regarding the sustainability of the ways in which the triadic or T-model creates, communicates, captures, and delivers value. The purpose of this paper is to analyze the triadic business model, focusing on how it creates value for different actors, with the intention to identify both success factors as well as factors that jeopardise sustainability of the model.

With this effort, four main contributions are made to the literature. First, insights derived from prior and current research on value creation in T-models are synthesized, supplemented with an analysis of value creation in current T-model organizations, and organized into a conceptual framework capturing value creation in T-models. The authors believe this effort was necessary to obtain a unified view of this phenomenon that will help both researchers and practitioners to better understand how value is created within these business models. Second, Osterwalder's business model canvas is one of the most dominant frameworks in business model innovation research and practice (Osterwalder and Pigneur, 2010), yet it is tailored toward the M-based business model. This paper presents an adaptation of the traditional business model canvas to better reflect the T-based business model. Such effort is necessary to help reduce the difference between the academic focus on understanding value creation in business models on the one hand, and the managerial need to develop strategies that can help accommodate the new reality of T-models.

Third, this article connects with research discussing value co-destruction (Echeverri and Skålén, 2011; Vafeas et al., 2016) and outlines challenges to sustainable value creation in Tmodels. The analysis reveals that an increase in the number of T-models within an economy might create negative consequences for the individual, the organization, and society. A critical analysis is provided of the issues each of these levels may face, and the challenges they 
represent. Hence, this paper shows how business model innovation may lead to the creation of value for one or just a few actors, yet may also destroy value for (potentially) many others. Finally, a research agenda is proposed that outlines some of the most pressing research questions and may help shape academic research in the years to come.

\section{Research background}

\subsection{New types of business models}

Recently, several studies discussing the T-based business model have used slightly different terminologies, implying different interpretations of the phenomenon. Notably, Perren and Kozinets (2018) use the term 'lateral exchange markets' to build a prototype and to describe sites facilitating technologically-intermediated exchange between actors. The authors aim to understand and differentiate between peer-to-peer, sharing, and access-based markets. Benoit et al. (2017) focus on the term 'collaborative consumption' to describe business models that operate with a triangle of actors; a platform provider, a peer service provider and a customer. In so doing, they make an effort to distinguish this form of business model from non-mediated concepts like peer-to-peer sharing and renting. In addition to these two terms, aspects related to T-models can be found in the sharing economy (Breidbach and Brodie, 2017; Hamari et al., 2016; Roh, 2016). Other research has focused on context-specific platforms, such as platforms for crowdsourcing (e.g., Kohler, 2015; Nucciarelli et al., 2017; Tung and Jordann, 2017), education (Anderson and Van Wijk, 2010) and health care (Solaimani et al., 2015).

Overall, the T-model has shaken up and will continue to shake up established industries that are typically based on the M-model (Belk, 2014; Chandler 1962), including personal computers, academia, banks, consulting, private transportation, retailing, hospitality, and media. Zervas et al. (2017), for example, show that the entry of Airbnb on the Texas market created a 
drop in hotel revenues by about 8 percent to 10 percent, especially for low-end hotels and hotels which are most vulnerable to Airbnb substitution. In the market for automobiles, the number of customers engaging in car sharing has increased from 52,000 users in 2004 to 1.28 million users in 2015 (Shaheen and Cohen, 2015), leading traditional car manufacturers to fundamentally rethink their current product offering and operations (Bellos et al., 2017). Given the T-model's potential to disrupt traditional businesses, organizations adopting such business model typically have high levels of market capitalization. Not surprisingly, companies included in the world's top-ten list of most valuable companies, e.g., Amazon, Uber, Lyft, eBay and Airbnb, are proponents of a T-model, acting as middleman between buyers and suppliers of assets or labor. Interestingly, the T-model's success in creating value for customers and investors is explained by Munger (2015 p. 199) as an effect of "a middleman who sells reduction in transaction costs". In other words, value created for customers and investors is solely due to reduced transaction costs (Coase, 1937; Williamson, 1981). While transaction costs are indeed reduced, it can be argued that the T-model's success is also explained by the new business model offering increased customer and supplier value added (Sexton, 2009). From the perspective of the supplier (i.e., a person offering assets or time to be utilized by others), there are the advantages of easy access to a global marketplace and easily promoting a business. For the buyer (i.e., a person making use of other people's idle assets or time), advantages lie in increased choice through access to a global market, cost-reductions, information, and potentially services that are better tailored to their personal needs.

Hence, business model innovation allows firms to innovate how they create, deliver, capture, and communicate value in new ways - often enabled by new technologies. Nowadays, Chandler's M-model (Chandler, 1962), which still is being used in many modern service 
companies, is challenged or supplemented by the T-model (Hagiu and Wright, 2015). As usual, the future will build on the past's forms of organizing economic activities, that is, the best from today will be the building blocks of the future. The market success of T-model based organizations leads the authors to predict that a gradual shift will be witnessed from M-based business models to the T-based business models in the years to come. Yet, a note must be made that the M-model will not become obsolete, but rather might be integrated in a T-model as suppliers and buyers including the platform need to be managed in one way, shape or form. The diffusion of technological innovations into various aspects of business will reduce the size and number of M-models, but elements of the M-model will likely remain somewhere in the system. In the following sections, major differences between the $\mathrm{M}$ - and the T-model are outlined.

\section{Comparing the M- model and the T-model}

Taking a more structured approach, several differences between the $\mathrm{M}$ and $\mathrm{T}$ business models can be discerned. Table 1 provides an overview of some of the major differences between the two models. Following Libert et al. 's (2016) typology, it can be argued that the traditional asset builders (e.g., Chrysler, making, marketing, distributing, and selling physical goods), service providers (e.g., McDonald's, hiring employees who provide services to customers), and technology providers (e.g., IBM, developing and selling intellectual property such as software analytics, and technology) use M-based business models, whereas network facilitators (e.g., Lyft, creating a network in which participants interact and share in the value creation) make use of a T-based business models. In reality, some hybrid models can be discerned, combining elements from the M-model and the T-model. Accordingly, the Norwegian neighborhood car sharing service Nabobil.no is organized as an M-model at its core and as a T-model toward the market by 
providing a platform through which buyers can connect directly with suppliers (i.e., owners of private cars).

Asset builders and service providers, such as large hotel chains and traditional universities, are more rigid/less agile in their adaptation to external changes, are more difficult to scale, are asset-heavy, and employ more people than for example Airbnb and mass open online courses (MOOCs). Organizations adopting a T-model are typically 100 percent digital, and light on assets (e.g., Uber does not own cars, Airbnb does not own any hotels) and labor (e.g., TaskRabbit does not employ workers). The effects are visible in some key performance indicators. Schwab (2016) compares the value creation in 1990 Detroit for three asset builders (Chrysler, Ford, and GM) with 2014 Silicon Valley for three network facilitators (Apple, Facebook, and Google (Alphabet today)). While revenue is similar for the three companies in the two time periods, the number of employees and market cap is $127.000(-10 \mathrm{x})$ and USD 1, 09 trillion $(+40 \mathrm{x})$ in favour of the three network facilitators from Silicon Valley.

From the above examples T-based business models are significantly different from Mbased business models in the way they create, communicate, deliver, and capture value. First, traditional business models are dyadic in nature where the basic philosophy consists of selling or renting products or services to a buyer (Benoit et al., 2017). In contrast, T-models are triadic (representing three or more groups of actors). M-models sell goods or services and in the process transfers ownership to buyers in exchange for money. In contrast, T-models give buyers the right to use supplier's assets or time for a limited time, i.e., no ownership. The company facilitating the exchange (of labor or assets) between suppliers and buyers needs to attract both suppliers and buyers to the platform. Often, companies operating within an M-model have a more hierarchical and fixed organizational structure, while companies operating within a T-model are more 
flexible and generally network based. In addition, T-models are often not bound to a specific location and are highly scalable. Usually, companies operating within a T-model have lower initial costs as capacity investments (e.g., number of rooms) are not tied to fixed assets (e.g., a hotel). While there can be costs in investing in IT-infrastructure, usually these companies have lower costs with respect to acquiring and maintaining tangible assets and transaction costs.

- Insert Table 1 about here -

With a better understanding of how T-models differ from M-models, the next section elaborates on the value creation process in T-models as a foundation for a better understanding of why these firms are so highly valued by investors.

\section{Value-creation in T-models}

To repeat, there are three categories of actors in the T-model: suppliers (i.e., the actor who is offering time or assets to buyers through the platform), buyers (i.e., the actor who is making use of the supplier's time or assets for a pre-defined time period), and the platform organization (i.e., the actor who acts as middleman connecting suppliers and buyers). The platform organization refers to the organization that owns and operates the services that facilitate interactions and transactions between suppliers and buyers of labor and assets (Benoit et al., 2017; Perren and Kozinets, 2018). The platform organization reaps financial (returns on investment) and other benefits (brand equity, visibility) from the operation of the platform. Figure 1 outlines the fundamental elements involved in the value creation process in the T-model. These elements are a synthesis of concepts that are core to the value co-creation literature (Brodie et al., 2006), relationship marketing (Morgan and Hunt, 1994) and the business model innovation literature (Foss and Saebi, 2017). In the following paragraphs, each of the elements and their roles within 
the model are discussed in more detail. First, strategic choices, i.e., choices that form the starting points for numerous decisions pertaining to, for example, strategy and brand positioning are explored. In many ways, it can be argued that these strategic choices are not too different from those that need to be made in an M-model.

- Insert Figure 1 here -

\subsection{Strategic choices}

Strategic choices are the fundamental decisions made by the platform company that shape the purpose and the value propositions of the platform company. These include decisions pertaining to the degree of facilitation and innovation (Chatterji and Fabrizio, 2014), the degree of contractual or relational involvement (Cao and Lumineau, 2015), the degree and type of control (Rustagi et al., 2008), and brand positioning (see for example Keller, 1993). In the next section, these terms will be elaborated upon and defined.

\subsubsection{Degree of facilitation and innovation}

The degree of facilitation can be defined as the way and the extent to which technology is used to facilitate the exchange of service between suppliers and buyers. By influencing the number and nature of facilitating and complementary service elements it affects the ease of use and the usefulness of the interaction and transactions (Nysveen and Pedersen, 2005). Innovation refers to the amount of resources spent on improving the technology and the resulting buyer and supplier experiences (and the cost structure). Uber, for example, uses an application that combines technological features of geolocation (i.e., locating the customer and the Uber driver and offering driving directions), push notifications and text messaging services (e.g., sending a message to the customer when the driver is only a minute away), and payment integration (i.e., offering a convenient payment system, so that cash payments become redundant). While the level of 
technology in the Uber application is fairly limited, the unique combination of these technologies in a traditional setting created a level of facilitation (and associated customer experience) unparalleled by traditional taxi companies.

\subsubsection{Degree of contractual involvement}

With the purpose of limiting risks and liability for buyers and sellers including its own brand equity, the platform company will invest in setting up contractual arrangements with various parties. Inherent risk can be shifted from or toward other stakeholders to various degrees and in various ways (e.g., legal, financial, HR, brand). While some platform companies, e.g., Craigslist, will only connect buyers and sellers, Airbnb will, upon request, intervene in the transaction if there is a dispute between buyer and seller. Active involvement of the platform company will reduce buyers' and sellers' perceived risk, i.e., reduced enforcement costs (Coase 1937), of entering into a contractual agreement between strangers.

\subsubsection{Degree of control}

Degree of control refers to how the platform company curates the coordinated and balanced growth of customers and suppliers with the goal of maximizing supplier-buyer matching. For example, too many buyers relative to sellers will increase prices, while the reverse will lead to a price reduction. Predictable prices are in all parties' interest. Some actors use dynamic pricing. Amazon, for example, changes the price on objects as a function of time of day when online buyers are more active. Uber uses a surge pricing strategy: During moments with excessive demand (peak hours or holidays), Uber charges a premium for a ride in an attempt to encourage drivers to supply their services and to discourage demand from users in peak times. In addition to 
the price mechanism, consumers are calling for an extensive set of regulatory measures as they consider other platform users may be opportunistic, leading to problems in the resource sharing process (Hartl et al., 2016). Active curation also includes the process of better matching what suppliers and customers are looking for, i.e., assets or labor, by for example the use of filters and algorithms and artificial intelligence (AI) allowing the algorithm to learn from buyers' and sellers' preferences.

Conversely, trust is often considered the currency of the platform economy (e.g., Etzioni, 2017). The basic idea is that organizations should foster trust among platform users rather than exerting control. The most commonly used tactic is to create a norm and a community feeling among platform users through socialization tactics such as events or online communities and social media (Habibi et al., 2017).

\subsubsection{Brand Positioning}

One of the functions of the brand is to send strong signals to the market pertaining to value propositions and market offerings (see, for example, Connelly et al., 2011) allowing prospective buyers and sellers to make the right choice pertaining to which platform provider to engage, e.g., Lyft or Uber. Second, the platform service must be positioned with respect to competing offers, i.e., offers related to which job customers and suppliers want to get done when they "hire" the platform to do the job for them (Christensen et al., 2017), and not least how they want that job to be done. Branding and signalling are well-established concepts in marketing (see, for example, Keller et al., 2011). From a strategy and operational perspective, the company may, for example, decide to focus on cost leadership, operational excellence or customer intimacy (see for example Treacy and Wiersema, 1993). One key concern related to branding is related to the positioning of 
the platform as a sustainable alternative or extension to traditional M-models. Given its focus on the reuse of assets, the use of underutilized assets, and lower reliance on extraction of raw materials, platforms often tend to position themselves as sustainable alternatives to traditional businesses. A sustainable business model not only creates, delivers, communicates, and captures value to the benefit of owners and customers but in concert with the environment and society (Boons et al., 2013). Most buyers, however, engage with a platform out of economic or purely utilitarian reasons (Benoit et al., 2017). The strategic choices for platforms discussed in Section four are developed through a number of factors including management of resources processes and customers and suppliers'. These are discussed next.

\section{T-Model factors}

\subsection{Managing risk}

The three parties in the triadic business model face different kinds of risks (Perren and Kozinets 2018). In the following, the platform, supplier and buyer risk will be discussed.

\subsubsection{Managing the platform's inherent risks.}

The platform company is faced with several risks that need to be neutralized, mitigated, or managed. Depending on the strategic choices that have been made, different forms of risk offer different types and degrees of threats. In the case of TaskRabbit, a platform owned by IKEA linking handymen to customers, bad experiences of either customers or labor suppliers could create a risk through negative spill overs, i.e., negative word of mouth or mouse, to the IKEA brand thereby reducing its brand equity (Lemon et al., 2001). While platform or access brands do not necessarily affect the parent brand negatively (Baumeister et al., 2015), it would be important to identify different sources of bad experiences, especially the kind that could easily be 
attributed to the platform, such as missed appointments (the system is responsible for matching availabilities of customer and worker, i.e., for making the appointment). The platform's business policy and practice need to be carefully monitored with a view to minimize customer dissatisfaction or strong emotional responses like rage (McColl-Kennedy et al., 2009). The platform can also experience opportunism from the buyer or the supplier, e.g., suppliers that over time sublet rooms or apartments directly without paying the fee to the platform company.

\subsubsection{Managing suppliers' risk}

Managing suppliers' risk includes managing the risk that suppliers' assets are damaged by buyers, or not used optimally, or the abuse of the supplier's labor. Suppliers may also experience opportunism from customers that do not show up, refuse to pay, or treat the supplier, in the role of frontline employee, badly. The traditional approach to managing supplier risk is by offering insurance; the user of the asset is expected to make a deposit and allow the supplier of the asset to file claims in case damage occurs (Weber, 2014). The need for insuring platform users has given rise to an entirely new business opportunity for financial service providers.

Another way of managing supplier risk is through the use of ratings and recommendation systems (Kim and Yoon, 2016). Ratings and reviews reduce transaction costs (Coase, 1937), drive out rotten apples (Akerlof, 1970), and serve as signals that can help reduce information asymmetry for the supplier (Aboody and Baruch, 2000). One pertinent question reflecting information asymmetry is: Is this customer, supplier, or platform reliable or not? The need for ratings and reviews has given rise to a new phenomenon, one in which the service provider rates the customer and vice versa. Uber, for example, asks their drivers to offer passenger ratings ranging from one (unreliable and not worth picking up) to five (reliable and worth picking up). 
This new approach is considered so successful in reducing customer misbehaviour, that industry experts are calling for the use of similar ratings in traditional industries like hospitality, airlines, or financial services (Weinstein, 2017). One such service is the controversial ratemyprofessors.com which allows students to rate their professor. Being able to rate each other is critical for an evolution toward cooperation (Axelrod and Hamilton, 1981). How customers react to being evaluated by suppliers, rather than the reverse, remains unclear to date.

\subsubsection{Managing customers' risk}

For customers, risk can be related to buying from strangers, the quality of the product or service (Akerlof, 1970) or other issues related to safety or a lack of insurance. Customers can experience opportunistic behaviour from the supplier: e.g., rooms that are not available anymore as other customers have offered a higher price, or drivers that ditch customers in favour of longer and better paid trips. The shift from an M-model to a T-model has given rise to an entirely new set of risks that need to be managed. For example, in collaborative consumption (and also access-based consumption) consumers might fear issues of health and safety such as cleanliness and catching germs, facing product unavailability, facing a lack of trust in others, finding the service impractical or overly complicated, and even being perceived more negatively by others because of using a platform service, among others (Edbring et al., 2016). The use of ratings and recommendation systems can thus help reducing customers' risks, i.e., reduce shirking. Customers can discern whether a supplier will live up to his or her promises or not.

\subsection{Managing loyalty}


In the T-model, loyalty is a three-sided phenomenon: buyers' and sellers' loyalty to the platform and the platform's loyalty to buyers and sellers. In some cases, loyalty may even exist between buyers and sellers. In the following, more background pertaining to managing buyer and seller loyalty is provided.

\subsubsection{Managing supplier loyalty}

Platform organizations face the challenge of building a profitable buyer base while sustaining a critical mass of service providers (i.e., suppliers). Hence, they not only need to manage buyer loyalty but also need to sustain supplier loyalty. Supplier loyalty to the platform is all about suppliers' willingness to keep offering assets and/or labor on the platform, and to provide positive word of mouth/mouse thus attracting similar suppliers to the platform. Currently, platforms are facing high levels of supplier churn. For example, Uber faces an annual driver churn of about 30 percent (Hall and Krueger, 2015), which is oftentimes the result of the lack of autonomy in deciding which buyers to serve, the dissatisfaction with the compensation they receive, the lack of involvement in change management, the need to purchase insurances themselves, a lack of response to concerns from the platform provider, and/or simply time constraints. At the same time, the exit barriers are low. Suppliers typically are not highly committed to a platform provider as evidenced by them offering their assets or time through competing platforms, leading them to churn more easily (Kumar et al., 2018). In line with studies showing a negative effect of employee turnover on service quality in regular services (Subramony and Holtom, 2012), a high turnover of suppliers in a T-model is associated with a decrease in service quality and an increase in customer complaints (Kumar et al., 2018). As a result, platform organizations can increase supplier retention by addressing some of the aforementioned concerns. 


\subsubsection{Managing buyer loyalty}

Buyer or customer loyalty is defined as "a deeply held commitment to rebuy or repatronize a preferred product/service consistently in the future, thereby causing repetitive same-brand or same brand-set purchasing, despite situational influences and marketing efforts having the potential to cause switching behavior" (Oliver, 1997, p. 392). Yang et al. (2017) found in their study of various platform services that confidence, social and relational safety benefits are drivers of commitment and ultimately loyalty. Möhlmann (2015) found that satisfaction and likelihood of repurchasing platform services are determined by self-serving benefits. Utility, trust, cost savings, and familiarity are particularly important to loyalty, while service quality and community belongingness are of importance too in some service categories. For the platform company, customer loyalty is associated with giving positive word of mouth and being likely to use the service again.

In order to effectively manage buyer loyalty, Kumar et al. (2018) recommend the use of customer lifetime value (CLV) and customer engagement value (CEV) metrics to identify and retain profitable customers, growing the customer base by implementing a customer acquisition strategy across or within generational segments, and develop win-back offers for valuable defected customers. These metrics should be relatively easy to calculate given the availability of transactional data within the platform organization.

\subsection{Managing buyer and supplier selection}

In marketing, matching customer preferences with supplier preferences, i.e., homogeneous preferences, is key to customer satisfaction (Fornell, 1992). In real life, this implies selecting the "right" customers and suppliers to the platform's value proposition for the purpose of creating a good match for long-lasting, sustaining relationships (Zelizer, 2007). From a supplier 
perspective, the dominant view is that suppliers are often able to participate without strict requirements and without professional training (Yang et al., 2017). Platform organizations maintain such a strategy as they need to create sufficient supply to meet customer demand and grow their business. In the absence of supplier selection criteria, i.e. curating the platform through filters, algorithms, and artificial intelligence, may cause significant variations in the customer experience that may ultimately lead to customer churn. As the platform economy grows, more stringent supplier selection processes and efficient methods of matching suppliers with target buyers are necessary to ensure service quality, value creation and customer satisfaction.

In addition, the use of a rating system creates an additional selection mechanism by allowing buyers or suppliers to change behavior and receive higher ratings or simply be excluded when few if any suppliers/buyers select them. Underperforming suppliers or impolite customers are more likely to receive lower ratings, after which they are less likely to be selected in the future. Some platform organizations take a more proactive stance. Airbnb, for example, delists suppliers if they do not meet the minimum hospitality standards or do not comply with the platform's regulations. In the same way, Uber will intervene when drivers receive low ratings from customers. They do this to protect buyers' interests and their own brand equity by avoiding negative word of mouth/mouse.

\subsection{Managing the Customer Experience}

Customer experience is defined as a "a multidimensional construct focusing on a customer's cognitive, emotional, behavioural, sensorial and social response to a firm's offerings during the customer's entire purchase journey" (Lemon and Verhoef, 2016, p. 71). Thus, managing the customer experience implies managing all the touchpoints on the customer journey, from A to Z 
in such a way that it triggers positive customer responses, including cognitive, emotional, and behavioral. The ability to deliver a compelling customer experience is very often what drives value creation in a platform economy.

For example, Uber is often considered as outperforming the traditional taxi industry because it is able to deliver a better customer experience on three main factors: (i) the geolocation feature, which allows customers to know exactly where the driver is and when he/she will arrive (versus the uncertainty of whether and when a traditional taxi will show up), (ii) the knowledge about the driver, as customers know who the Uber driver is and how he or she performed with other customers (versus the uncertainty of who the taxi driver will be when the taxi shows up), and (iii) the predictability of costs, as a customer knows up front how much a certain trip is going to cost (versus the situation where a customer enters a taxi not knowing how much he is expected to pay in the end, and whether the taxi driver accepts credit cards). This example illustrates that platform organizations might attain a competitive advantage over traditional, M-model based organizations through an extensive customer journey analysis and removing the points of dissatisfaction associated with traditional providers.

Yet, managing the customer experience in a platform economy is more challenging than it seems. First, customers oftentimes have to go through more extensive customer journeys before being able to benefit from the asset or labor than when using traditional approaches (i.e., ownership of assets or use of traditional service providers). For example, customers using car sharing need to carefully plan the use of the car, make a reservation, pick up the car from a certain location or with another consumer, check the car for damages before actual usage, actually use it, and return it once it is no longer needed, among others. Customers perform these 
activities, i.e., increased transaction costs, with a high level of participation but with minimal to no supervision by the platform organization (Hazée et al., 2017).

Second, platform organizations are expected to manage the customer experience and the customer journey while relying on suppliers of assets or labor that did not go through a screening process as thorough as when hiring 'traditional' employees, and/or lack professional training (Yang et al., 2017). As a result of not owning strategic resources (Pfeffer and Salancik, 1978), the platform organization can exert less control over how value is (co)created within the Tmodel. Buyers face significant levels of heterogeneity in the platform organization's offering, which results in significant increases in buyer complaints (Kumar et al., 2018). To date, buyers have low expectations regarding the level of problem resolution offered by platform organizations. In a study of Airbnb customers, for example, Guttentag et al., (2017) show that buyers have relatively low expectations regarding Airbnb's ability to deal with unexpected problems and failures; these expectations are significantly lower for Airbnb than for mid-range and upscale hotels.

Hence, managing the buyer experience requires platform organizations to exert more control over the supplier's offering (e.g., by providing clear guidelines about which buyer experience should be delivered) but also investing significantly in effective problem resolution activities (see Van Vaerenbergh and Orsingher, 2016 for a review). Despite the extensive focus on customer experience in managerial discourse, studies outlining what constitutes the buyer experience are rare and even more so in the context of the platform economy.

\subsection{Managing suppliers' attractiveness}

To attract and retain buyers, suppliers need to offer a better value proposition, i.e., be perceived as relatively more attractive, than other suppliers of the same goods or services (Andreassen and 
Lervik, 1999). These authors document that quality and customer satisfaction are important drivers of relative attractiveness resulting in customer loyalty. Thus, the suppliers need to have insight in buyers' preferences and needs, such that they can offer a high level of quality to attract and retain buyers through the platform. Finally, the supplier's value proposition must be perceived as more attractive than value derived from ownership over the asset or customers performing a task themselves. Positive ratings and reviews from existing customer also enhance the attractiveness of suppliers, as they are associated with higher levels of economic value (Teubner et al., 2017). Several studies highlight aspects of ratings and reviews that increase attractiveness to customers, such as adding photographic material (Ert et al., 2016) or using storytelling (Pera, 2017).

\subsection{Designing, communicating and maintaining value propositions}

Anchored in the platform's strategy, the value proposition communicates how multidimensional value (benefits) will be co-created with, experienced and acquired by suppliers and buyers. Different platforms will have different value propositions, depending on whether they are forums, enablers, matchmakers or hubs (Perren and Kozinets, 2018) and different value propositions need to be formulated for the end-user side and the business side, i.e., the supplier (Muzellec et al., 2015).

\subsection{Managing and maintaining the marketplace}

Managing and maintaining the marketplace refers to the commercial activity of building the brand, attracting new buyers and sellers, curating, and managing supply and demand.

Specifically, curating the market place so that buyers and sellers are matched in an optimal way as the number of buyers and sellers grow is seen as critical. Using AI, algorithms and filters, this 
can be done in an efficient and effective way. Platforms that are curated professionally will have significantly more satisfied buyers and sellers with a higher probability of returning actors (Fornell, 1992).

\subsection{Managing resources}

The platform company will use different forms and resources to perform its vital functions. The use of resources needs to be managed and adapted to the development of the company. Depending on where the firm is in its life cycle, management needs to make available various resources, capital and human resources, to the other stakeholders, such as IT technology and capacity, a help desk, training, or an app.

\section{The Triadic Business Model Canvas}

The triadic value-creation perspective is central to T-models, that is, the business should be of value to all three parties involved. Customer value added is the difference between perceived value - the maximum a buyer will pay for a service and the incremental cost of providing that service (Sexton, 2009), which is a function of the value in use when the buyer decides to make use of the platform firm's value proposition and experiences the supplier's value proposition. In line with this logic, both supplier and buyer will experience value added, which triggers their intentions to be loyal to the platform. In the same way, the platform extracts value from buyers and sellers and thus has an incentive to create loyalty to buyers and sellers.

A business model canvas (see for example Osterwalder and Pigneur, 2010) summarizes the characteristics of a business model, which enables companies to map their core business activities and identify areas for improvement, better integration, and differentiation. Existing business model canvases are modeled on manufacturing and hierarchical organizations, i.e., M-models, and not 
that well-suited for T-models. In Figure 2, a comprehensive overview is provided of the core contributors to value creation and the threats to the sustainability of that value creation, or risks, in T-model businesses.

\section{- Insert Figure 2 here -}

Rather than providing a single value proposition to a market, as is the case in the traditional M-model providers, the T-model platform stresses the fact that two separate comprehensive value propositions need to be developed. One value proposition needs to be offered to the buyer, and one to the supplier of services or products, because the engagement of both stakeholder categories is crucial to the sustainability of the model. Both value propositions are essentially based on cocreation, since suppliers and buyers co-create the value with or through the platform. Value proposed to the customers and to the suppliers in this model is fundamentally multidimensional, and determines the degree of retention, loyalty or engagement of these stakeholders. This is reflected in Figure 2 by including the 7 P's of the marketing mix, which together and in their unique composition determine the value propositions. The value created in the T-model is, in this sense, more than simply reduced transaction costs.

Apart from the two multidimensional value propositions toward suppliers and buyers, the platform company must make a range of strategic decisions, and take actions, regarding the overall branding strategy, up- or down scaling, selection of customers (i.e., segments), and supplier selection, to support the total value creation of the T-model based business. Each of the elements in Figure 2 can be used by the platform company to identify the involved stakeholders, and related business activities that are required to sustainably generate value in a triadic business model. Based on the identification of these stakeholders and business activities, strategic decisions can be made regarding the way value is generated. 


\section{Value-destruction in T-models}

Research on value co-creation has largely focused on the positive side, particularly focusing on the roles of the buyer and supplier (Chowdhury et al., 2016). There is little research on the dark side of value co-creation, or value co-destruction, with some exceptions (e.g., Echeverri and Skålén, 2011), and none that the authors know of on the dark side of T-based business models. Such business models ultimately lead to value creation through their efficient enabling of interactions between suppliers and buyers through a platform. As with all interactions in the context of relationships the interaction process between actors is not always harmonious. This is particularly likely within a network of actors as multiple actors interact increasing the potential for suboptimal outcomes (Chowdhury et al., 2016).

The following section addresses the dark side of interactions recognising three levels of the platform economy, micro (the individual), meso (firm or organization) and meso/macro (unions, professional associations, community/government and societal level), with particular reference to the case of Uber, the global high-profile and controversial ride sharing T-Model based company. Uber is topical at the time of writing this study, since this coincided with the end of a long but ultimately successful defence of its licence in the British market, at the end of June 2018. The discussion will be confined to a number of core challenges of conducting business through a T-model. While other challenges can be identified, this article focuses on a small number for which future perspectives are offered, for reasons of parsimony.

\subsection{Micro level}

The emergence of the sharing economy has led to a series of unregulated marketplaces that pose a threat to consumers and regulated businesses. One major challenge is that risks are often 
transferred to consumers, i.e., adverse selection (Wilson, 2008). For example, Uber drivers are not fully insured, (Martin, 2016). Furthermore, Uber does not have commercial licenses, which offer drivers some protection in terms of problematic customers and rights of appeal, as well as offering passengers_safety standards in terms of the vehicle and the credibility of the taxi organization and the driver (Boshuijzen and Haftor, 2015; Malhotra and Alstyne, 2014). This lack of regulation which creates adverse selection, can, if a buyer is injured, have significant negative implications for the reputation of Uber and maintenance of the value proposition at both the industry level as well as among suppliers and most particularly buyers, such as passengers concerned over safety (Deloitte, 2015).

While the sharing economy portrays workers conditions in terms of 'happy people working for themselves' this is an illusion in many cases as discussed by Subramony et al. (2018). For example, as more drivers join Uber, wages decrease, due to supply and demand (Henton and Windekilde, 2016). Drivers will adjust their hours and their locations to satisfy demand, algorithms determining their schedule, negating the concept of being one's own boss (Biggins, 2017). This non-transparent process also has implications for the customer, who is forced to accept a dynamic business practice (Deloitte, 2015). This challenge also applies to brand extensions of platforms such as Uber-eats. For example, some restaurant managers have found that the costs of supporting the marketing and operational side of this concept are not justifiable (Rodriguez, 2018). Dissatisfied suppliers and buyers will impact the attractiveness of the platform and may damage the long-term viability of assuring supply and maintaining the marketplace. 
So, what of the future for T-model actors? Self-employment will increase and approach 33 percent of the workforce in the coming years (Bresiger, 2018). In most European societies, the labor market is organized along three categories of actors - the government, labor unions, and employer unions. This model assumes contractual employment as the dominant and preferred form for employees to connect with firms and organizations. As employees, people have a more regulated work contract, e.g., pensions, paid vacation or maternity leave, defined work-hours including lunch breaks, etc., the nature of service workers' employment is being challenged (Subramony et al., 2018). Many T-model based firms opt to not employ frontline employees. When employees are outsourced to a market and not employed, but rather short-term contracted, - service firms not only abandon the norms of employment but also lose control over the service provision, including the interactive element of the service delivery which is critical to perceived service quality, reducing customer satisfaction and leading to negative word of mouth/mouse.

\subsection{Meso level}

A dark side factor of the platform economy at the industry level is the implications for workers in traditional competing businesses such as drivers of traditional taxis. Licensed taxi drivers incur higher fixed costs, such as licenses, exams and regulations and insurance, while ride sharers can exploit such loopholes to avoid rules and taxes (Malhotra and Alstyne, 2014). The taxi industry has protested that rideshare businesses and regular taxi drivers operate in the same market, yet under different apparent rules, for example inadequate checks on Uber drivers and vehicles and non-compliance with legal requirements, inadequate insurance and workers' compensation, no industrial relations agreements and surge pricing (Deloitte, 2015) creating unfair business practices. 
T-model platforms may render many jobs such as middlemen, out of date, at best or redundant at worst (World Economic Forum, 2018). Regular taxi drivers have complained that Uber floods the market with drivers and cheap fares, reducing customer demand for traditional drivers in a market where competition is already high (Boshuijzen and Haftor, 2015). This has led to extreme impacts on regular taxi drivers in the industry including several New York City Taxi drivers committing suicides (Stewart and Ferré-Sadurní, 2018). In time, platforms, by covering only marginal costs, pay only for short-term expenses, with little consideration for the broader future in terms of training, healthcare and retirement for the supplier (Malhotra and Alstyne, 2014) or regulations the incumbents are forced to obey. A marginal supply orientation may have implications for the longer-term reputation and the availability of resources and guaranteeing platform suppliers (e.g., Uber drivers) in the future, thus potentially damaging the market in the long term. From a theoretical perspective, not owning strategic resources is in contradiction to Resource Dependency Theory (Pfeffer and Salancik, 1978) which dictates that a successful business model requires that the organization maintains control of its core assets; that is employees in labor-focused, rather than asset-focused platforms, such as drivers in the case of Uber or handymen in the case of Ikea's TaskRabbit.

Further, at this meso level, the core value proposition of the platform is potentially eroded as collaborative consumption goes mainstream, and risks losing the original unique value that attracted buyers, sellers and platform providers in the first place. Such value comes about through the unique and often transformative experiences that occur when buyers interact with helpful suppliers who are essentially strangers (Henton and Windekilde, 2016). Furthermore, the maintenance of the value proposition can be challenging with the three or multi-sided model, in that resources from two or more sides need to be matched to support the proposition. For 
example, Uber's competitor Sidecar exited the market following offering a complicated service offering in which drivers needed to decide on rates and passengers on cars and wait times. Similarly, Zipcar failed to engage customers in a brand community as users did not feel a sense of attachment or identification with the cars (Habibi et al., 2017).

\subsection{Macro level}

The platform economy can have long term impacts on higher level bodies such as unions and government, due to its unregulated nature (Martin, 2016). As T-model based firms in the form of, for example, sharing economy firms, are new to most societies and governments, the Organization of Economic Cooperation and Development (OECD) and some European Governments, including Norway, have formed expert committees to investigate how T-models should be taxed, how they should comply with/or not comply with current laws and regulations with the industry they enter, how labor laws should apply, and what tax incentives must be in place to create a peer-to-peer market for underutilized time and assets. These issues must be resolved in order to create a sustainable economy made up of $\mathrm{M}$ and T-model based firms.

Recent events in the case of Uber in the British market further demonstrate such regulatory need. Uber has experienced a significant setback in the British market, including legal challenges for example through the British Employment Tribunal and London's Transport Authority and corresponding court rulings. In September 2017, Uber was barred from operating in London due to its lack of corporate citizenship and disregard of government public transport requirements including not only insufficient background checks on drivers, but also the use of software to avoid disclosure of information to authorities and complaints of an aggressive, unrestrained workplace culture (Rao and Isaac, 2017). Since this time, in late 2017, the 
Employment Tribunal has also determined that Uber drivers are not self-employed, hence requiring that drivers receive a minimum wage and paid time off (Rao, 2017).

As a consequence, trust, which is a cornerstone of relationships, has been eroded in the case of Uber, specifically with respect to its ability to support the value proposition. Trust is negatively affected by opportunism, individualistic behaviour and power distance (e.g., Leonidou et al., 2013). In contrast shared values on goals and policies, strong regulations and control mechanisms, reputation and strong relationships all enhance trust. As McKinsey \& Co. strategists explained as far back as 1993 (Bleeke and Ernst, 1993, p. 1) "For most global businesses, the days of flat-out, predatory competition are over... In place of predation, many multinational companies are learning that they must collaborate to compete". A business operates in a society that it simultaneously both serves and depends upon, and to effectively compete a business must be a trusted co-operator in some network. Such trust involves the full range of actors in the business's ecosystem from suppliers, service providers, customers and other customers (Morgan and Hunt, 1994). These words from both sets of authors are as true today as they were then. External factors such as pressure from the traditional taxi industry, including protests and regular taxi driver suicides and lack of government regulations, make the transition to the platform economy/T-models challenging and controversial (e.g., Fitzsimmons, 2018). Given the evolving and dynamic industry for platform-based taxi services, maintaining trust will be a core priority. Further, public policy will need to ensure that regulations do not become outdated and are appropriate for the developing collaborative economy (Fehrer et al., 2018). 


\section{Summary}

In this article, the concept of T-models was introduced to the business model innovation literature, addressing the question: How is value created individually and collectively in triadic business models and what might challenge its sustainability? In response to this question, the paper identified, illustrated and presented the ways value is created in sustainable T-models, recognizing the triadic, collaborative nature of value co-creation among three parties: platform, buyers and sellers. In a future macro environment impacted by societal and technological advancement, threats to non-sustainable natural resources, population increases, migratory patterns across the world, the ageing of the population, and an increasingly mobile workforce a T-model approach can potentially offer significant opportunities for businesses. Next to being an innovative from a value creation perspective, the T-model also inherently creates a number of (social) risks for all parties involved, by de-institutionalizing relationships between the platform facilitator and the suppliers, and between buyers and suppliers. The overall conclusion is that in a T-model, value is created through a number of factors in addition to lower transaction costs. Furthermore, it is likely that T-models will be merged with, rather than completely replacing, current M-models. The degree of transition from M-models to T-models will likely depend on the digitalization of the industry, on customers and on the company. A comparison of the M and T-model is presented and a business model canvas for the T-model suggested.

Looking to the future, the authors of this article do not expect that T-models will completely replace M-models, but that more businesses will be operating on a continuum between M-and T-models. Technological innovations will link buyers and sellers more effectively and efficiently bringing us closer to the ultimate market transaction; yet in the context 
of technology and access to global markets, this requires interactions among parties who are often strangers; thus, trust is the ultimate oil in the platform firm machinery. In its extreme with the emerging Blockchain technology, the role of the middleman may not be required. It is anticipated, or at least hoped for, that platform firms striving to increase the sustainability of the platform model will have ruled out some of the early faults in the design of T-model organizations, and that successful platform operators will be those who embrace new technologies and newly developed marketing techniques that help them continuously improve their value propositions for both the suppliers and the customers.

\section{Future research opportunities}

In the previous sections of this paper, the authors have discussed the ways in which value is created and potentially destroyed when shifting from an M-model to a T-model. During the discussion, they have highlighted some issues that future research might consider addressing. The conceptual nature of the present study calls for empirical verification and validation of key concepts on the one hand, and for further exploration of the challenges that lie ahead on the other hand. Table 2 lists a set of specific research questions that need to be addressed in the years to come.

- Insert Table 2 here -

In addition to these specific research questions, some broad directions for future research relating to $\mathrm{M}$ and T-models were also specified. First, throughout this paper the assumption was made that the economic landscape will gradually move from an M-model into a hybrid M\&Tmodel, while other organizations will have to shift to a 'complete' T-model. This perspective raises questions about when and the extent to which organizations should move to the T-model, knowing that this shift may have significant consequences for assets and labor supply. To what 
extent can the M-model and T-model co-exist? How large are the segments of customers willing to engage in a T-model? How will these segments grow and change by 2050 , knowing that the current younger generation is considered as digital natives? What is the optimal path to go from an M-model to a T-model? In which industries is this shift most pressing? What is the role of the top management team, knowing that even a minor shift from $\mathrm{M}$ to $\mathrm{T}$ requires a realignment of the organizational structure, an implementation of required support systems and the development of new and relevant performance indicators, among others? What is the consequence of a larger proportion of T-models in an economy for the service delivery network? For example, if hotels were largely replaced with Airbnb what implications does this have on firms supplying hotels such as tour companies, restaurants, and housekeeping and other suppliers (Henton and Windekilde, 2016)?

The growth of the T-based organizations represents some significant challenges for the field of service research. Many service management and marketing frameworks and models have been developed for M-models. However, these frameworks and models might turn out to be inadequate in a T-model context. For example, the service-profit chain framework (Heskett et $a l ., 2015)$ assumes that investments in internal service quality will lead to employee satisfaction, retention and performance, which in turn spills over to customers. In a T-model, frontline employees are out of the equation and are replaced by independent suppliers over which the organization has little control. The service climate framework assumes that organizations should invest in creating a mutual understanding among frontline employees that providing service to customers is valued and rewarded (Bowen and Schneider, 2014). Such investment becomes more complicated in case of a T-model. The service blueprinting model specifies exactly how the service should be provided, which actions should be performed in the frontline, and how the 
back-office can support these activities (Shostack, 1984). These models assume that the organization can control another party's actions, which is a flawed assumption in the T-model context. Hence, we call service researchers to adapt existing frameworks or develop new ones in order to accommodate a changing business context.

In summary, given the challenges ahead at the micro, meso, macro and mega level, we believe a large-scale concerted effort is necessary to better understand value creation and to help avoid value destruction when shifting from an M-model to a T-model. These are exciting times for service researchers, as we have the opportunity to expand our disciplinary horizons. While service research traditionally combines insights from marketing, human resource management, and operations management, the T-model context creates a setting where input from law, political science, anthropology, and computer science, among others, is necessary to better understand the T-model and its consequences for real world impact.

\section{References}

Aboody, D. and Baruch, L. (2000), "Information asymmetry, R\&D, and insider gains", Journal of Finance, Vol. 55 No. 6, pp. 2747-2766.

Akerlof, George A. (1970), “The market for 'lemons': Quality uncertainty and the market mechanism”, The Quarterly Journal of Economics, Vol 84, No 3, pp 488-500.

Anderson, J. and Van Wijk, G. (2010), “Customized executive learning: A business model for the twenty-first century", Journal of Management Development, Vol. 29 No. 6, pp. 545-555.

Andreassen, T. W. and Lervik, L. (1999), "Perceived relative attractiveness today and tomorrow as predictors of future repurchase intention", Journal of Service Research, Vol. 2 No.2, pp. 164-172. 
Axelrod, R. and Hamilton W. D. (1981), “The evolution of cooperation”, Science, 211, pp 1390 $-96$.

Baumeister, C., Sherer, A. and von Wangenheim, F. (2015), "Branding access offers: the importance of product brands, ownership status, and spillover effects to parent brands", Journal of the Academy of Marketing Science, Vol. 43 No. 5, pp. 574-588.

Belk, R.W. (2014), "You are what you can access: Sharing and collaborative consumption online", Journal of Business Research, Vol. 67 No. 8, pp. 1595-1600.

Bellos, I., Ferguson, M. and Toktay, L.B. (2017), "The car sharing economy: Interaction of business model choice and product line design”, Manufacturing \& Service Operations Management, Vol. 19 No. 2, pp. 185-201.

Benoit, S., Baker, T.L., Bolton, R.N., Gruber, T. and Kandampully, J. (2017), "A triadic framework for collaborative consumption (CC): Motives, activities and resources \& capabilities of actors", Journal of Business Research, Vol. 79 No. 10, pp. 219-227.

Biggins, M. (2017), How the gig economy's promise became a lie. Retrieved March 2, 2018, from https://medium.com/@matthewbiggins/https-medium-com-matthewbiggins-how-thegig-economys-promise-became-a-lie-956296a90ea8.

Bleeke, J., and Ernst, D. (1993), Collaborating to Compete, John Wiley \& Sons, Inc., New York. Boons, Frank, Carlos Montalvo, Jaco Quist, and Marcus Wagner: (2013), “Sustainable innovation, business models and economic performance: an overview", Journal of Cleaner Production, 45, 1-8

Bresiger, G. (2018), "Self-employment is a rising trend in the American workforce", available at: https://nypost.com/2018/03/25/self-employment-is-a-rising-trend-in-the-american-workforce/ (accessed 20 June 2018). 
Boshuijzen-van Burken, C. and Haftor, D. M. (2015), "Complexities and dilemmas in the sharing economy: The Uber case", Dilemmas 2015, Papers from the 18th annual International Conference Dilemmas for Human Services: Organizing, Designing and Managing. Växjö, Sweden: Linnaeus University.

Bowen, D.E. \& Schneider, B. (2014), “A service climate synthesis and future research agenda", Journal of Service Research, Vol 17 No.1, pp. 5-22.

Breidbach, C.F. and Brodie, R.J. (2017), "Engagement platforms in the sharing economy: Conceptual foundations and research directions", Journal of Service Theory and Practice, Vol. 27 No.4, pp. 761-777.

Brodie, R., J., Pels, J., and Saren, M. (2006), "From goods-towards service centered marketing : Dangerous dichotomy or an emerging dominant logic?" in Lusch, R. F. \& Vargo, S. L. (Eds.), The Service Dominant Logic of Marketing, M. E. Sharpe Inc., New York, pp. 307-319.

Cao, Z. and Lumineau, F. (2015), "Revisiting the interplay between contractual and relational governance: A qualitative and meta-analytic investigation", Journal of Business Research, Vol. 33-34, pp. 15-42.

Chandler Jr., A.D. (1962), Strategy and Structure, Cambridge, MA: MIT Press.

Chatterji, A.K. and Farbizio, K.R. (2014), "Using users: When does external knowledge enhance corporate product innovation?", Strategic Management Journal, Vol. 35 No. 10, pp. 14271445.

Chowdhury, I.N., Gruber, T. and Zolkiewski, J. (2016), "Every cloud has a silver lining exploring the dark side of value co-creation in B2B service networks", Industrial Marketing Management, Vol. 55 May, pp. 97-109.

Coase, R.H. (1937), "The nature of the firm", Economica, Vol. 29 No. 4, pp. 368-405. 
Connelly, B. L., Certo, S. T., Ireland, R. D. and Reutzel, C. (2011), "Signaling Theory: A Review and Assessment". Journal of Management, Vol 37 No.1, pp. 39-67.

Christensen, C. M., Hall, T., Dillon, K., and Duncan, D. S. (2017), Competing Against Luck: The Story of Innovation and Customer Choice, Harper Business, New York.

Deloitte (2015), The Sharing Economy and the Competition and Consumer Act: Australian Competition and Consumer Commission, Deloitte Access Economics”, available at: https://www.accc.gov.au/publications/the-sharing-economy-and-the-competition-andconsumer-act (accessed 20 April 2018).

Echeverri, P., and Skålén, P. (2011), "Co-creation and co-destruction: A practice-theory based study of interactive value formation", Marketing Theory, Vol. 11 No.3, pp. 351-373.

Edbring, E.G., Lehner, M. and Mont, O. (2016), "Exploring consumer attitudes to alternatives models of consumption: Motivations and barriers”, Journal of Cleaner Production, Vol. 123 No. 1, pp. 5-15.

Ert, E., Fleischer, A. and Magen, N. (2016), "Trust and reputation in the sharing economy: The role of personal photos in AirBnB”, Tourism Management, Vol. 55 No. 1, pp. 62-73.

Etzioni, A. (2018), “Cyber trust”, Journal of Business Ethics, available at: 10.1007/s10551-017$3627-y$.

Fehrer, J. A., Benoit, S., Aksoy, L., Baker, T. L., Bell, S. J., Brodie, R. J., et al. (2018), "Future scenarios of the collaborative economy: Centrally orchestrated, social bubbles or decentralized autonomous?” Journal of Service Management, forthcoming,

Fitzsimmons, E. G. (2018), "Taxi drivers in New York are struggling. So are Uber drivers", available at: https://www.nytimes.com/2018/06/17/nyregion/uber-taxi-driversstruggle.html (accessed 26 June 2018). 
Fornell, C. (1992), "National customer satisfaction barometer: The Swedish experience", Journal of Marketing, Vol. 56 No. 1, pp. 6-21.

Foss, N.J. and Saebi, T. (2017), "Fifteen years of research on business model innovation: How far have we come, and where should we go?" Journal of Management, Vol. 43 No.1, pp. 200227.

Foss, N.J. and Saebi, T. (2018), "Business models and business model innovation: Between wicked and paradigmatic problems", Long Range Planning, Vol. 51 No.1, pp. 9-21.

Gatautis, R. (2017), "The rise of the platforms: Business model innovation perspectives", Inzinerine Ekonomika-Engineering Economics, Vol. 28 No. 5, pp. 585-591.

Guttentag, D., Smith, S., Potwarka, L. and Havitz, M. (2018), "Why tourists choose Airbnb: A motivation-based segmentation study", Journal of Travel Research, Vol. 57 No. 3, pp. 342359.

Habibi, M. R., Davidson, A., and Laroche, M. (2017), "What managers should know about the sharing economy", Business Horizons, Vol. 60, No. 1, pp. 113-121.

Hagiu, A. and Wright, J. (2015), "Multi-sided platforms", International Journal of Industrial Organization, Vol. 43 Supplement C, pp. 162-174.

Hall, J.V. and Krueger, A.B. (2015), “An analysis of the labor market for Uber's driver-partners in the United States", Princeton University Industrial Relations Section Working Paper, 587.

Hamari, J., Sjöklint, M. and Ukkonen, A. (2016), "The sharing economy: Why people participate in collaborative consumption", Journal of the Association for Information Science and Technology, Vol. 67 No. 9, pp. 2047-2059. 
Hartl, B., Hofmann, E. and Kirchler, E. (2016), "Do we need rules for "what's mine is yours"? Governance in collaborative consumption communities", Journal of Business Research, Vol. 69 No. 8, pp. 2756-2763.

Hazée, S., Delcourt, C. and Van Vaerenbergh, Y. (2017), "Burdens of access: Understanding customer barriers and barrier-attenuating practices in access-based services", Journal of Service Research, Vol. 20 No. 4, pp. 441-456.

Henten, A.H. and Windekilde, I.M. (2016), "Transaction costs and the sharing economy", INFO, Vol. 18 No. 1, pp. 1-15.

Heskett, J.L., Sasser, W.E. \& Schlesinger, L.A. (2015), What Great Service Leaders Know \& Do: Creating Breakthroughs in Service Firms, Oakland, CA: Berret-Koehler Publishers.

Jaworski, B. J. and Kohli, A. K. (1993), "Market orientation: Antecedents and consequences”, Journal of Marketing, Vol. 57 No. 3, pp. 53-70.

Keller, K.L. (1993), "Conceptualizing, measuring and managing customer-based brand equity", Journal of Marketing, Vol. 57 No. 1, pp. 1-22.

Keller, K. L., Apéria, T. and Georgson, M. (2011). Strategic Brand Management: A European Edition 2, Financial Times/Prentice Hall.

Kim, S. and Yoon, Y. (2016), "Recommendation system for sharing economy based on multidimensional trust model", Multimedia Tools and Applications, Vol. 75 No. 23, pp. $15297-15310$.

Kohler, T. (2015), "Crowdsourcing-based business models: how to create and capture value", California Management Review, Vol. 57 No. 4, pp. 63-84. 
Kumar, V., Lahiri, A. and Dogan, O.B. (2018), “A strategic framework for a profitable business model in the sharing economy", Industrial Marketing Management, Vol. 67 February 2018, pp. 147-160.

Lemon, K. N., Rust, R. T., and Zeithaml, V. A. (2001), "What drives customer equity", Marketing Managment, Vol. 10 No. 1, pp. 20-25.

Lemon, C.N. and Verhoef, P.C. (2016), "Understanding customer experience throughout the journey", Journal of Marketing, Vol. 80 No. 6, pp. 69-96.

Leonidou, L. C., Leonidou, C. N., and Kvasova, O. (2013), "Cultural drivers and trust outcomes of consumer perceptions of organizational unethical marketing behavior", European Journal of Marketing, Vol. 47 No.3/4, pp. 525-556.

Libert B., Beck. M. and Wind, J. (2016), The Network Imperative: How to Survive and Grow in the Age of Digital Business Models, Cambridge, MA: Harvard Business Review Press.

Lusch, R.F. and Nambisan, S. (2015), "Service innovation: A service-dominant logic perspective", MIS Quarterly, Vol. 39 No.1, pp. 155-175.

Malhotra, A. and Van Alstyne M. (2014), "The dark side of the sharing economy ... and how to lighten it", Communications of the ACM, Vol. 57 No. 11, pp. 24-27.

Marshall, W., van Alstyne, W., Parker, G.G. and Choudary, S.P. (2016a), "6 reasons why platforms fail", Harvard Business Review, Vol. 94 No. 4, pp. 2-5.

Marshall, W., van Alstyne, W., Parker, G.G. and Choudary, S.P. (2016b), "Pipelines, platforms, and the new rules of strategy: Scale now trumps differentiation", Harvard Business Review, Vol. 94 No. 4, pp. 54-62.

Martin, C.J. (2016), "The sharing economy: A pathway to sustainability or a nightmarish form of neoliberal capitalism?", Ecological Economics, Vol. 121 No 1, pp. 149-159. 
McColl-Kennedy, J., Patterson, P.G., Smith, A.K. and Brady, M.K. (2009), “Customer rage episodes: Emotions, expressions and behaviors", Journal of Retailing, Vol. 85 No. 2, pp. 222237.

Møhlmann, M. (2015), "Collaborative consumption: Determinants of satisfaction and the likelihood of using a sharing economy option again", Journal of Consumer Behaviour, Vol. 14 No. 3, pp.193-207.

Morgan, R. M., and Hunt, S. D. (1994), "The commitment-trust theory of relationship marketing", Journal of Marketing, Vol. 58 No. 3, pp. 20-38.

Munger, M.C. (2015), "The third entrepreneurial revolution: A middleman economy", Duke University. ", available at: http://www.econ.as.nyu.edu/docs/IO/37424/Munger_Third_Entrepreneurial_Revolution2.pdf (accessed 14 November 2017).

Muzellec, L., Ronteau, S. and Lambkin, M. (2015), "Two-sided Internet platforms: A business model lifecycle perspective", Industrial Marketing Management, Vol. 45 February, pp. 139150.

Nucciarelli, A., Li, F., Fernandes, K.J., Goumagias, N., Cabras, I., Devlin, S., Kudenko, D., et al. (2017), "From value chains to technological platforms: The effects of crowdfunding in the digital game industry", Journal of Business Research, Vol. 78 No. 9, pp. 341-352.

Nysveen, H. and Pedersen, P.E. (2005) "Intentions to use mobile services: Antecedents and cross-service comparisons", Journal of the Academy of Marketing Science, Vol. 33 No. 3, pp. $330-346$.

Oliver, R.L. (1997), Satisfaction: A Behavioral Perspective on the Consumer, New York: Irwin/McGraw-Hill. 
Osterwalder, A. and Pigneur, Y. (2010), Business Model Generation, Wiley, Hoboken, NJ.

Pera, R. (2017), "Empowering the new traveller: Storytelling as a co-creative behavior in tourism”, Current Issues in Tourism, Vol. 20 No. 4, pp. 331-338.

Perren, R. and Kozinets, R.V. (2018), "Lateral exchange markets: How social platforms operate in a networked economy", Journal of Marketing, Vol. 82 No. 1, pp. 20-36.

Pfeffer, J. and Salancik, G.R. (1978), The External Control of Organizations: A Resource Dependence Perspective, New York, NY, Harper and Row.

Rao, P. S. (2017), "Uber hit with new blow in London as panel says drivers aren’t selfemployed" available at: https://www.nytimes.com/2017/11/10/business/uk-uber-london.html (accessed 25 June 2018).

Rao, P. S., and Isaac, M. (2017), "Uber loses license to operate in London ", available at: https://www.nytimes.com/2017/09/22/business/uber-london.html (accessed 26 June 2018).

Rodriguez, V. (2018), Uber eats - "a necessary evil"? available at https://www.foodabletv.com/blog/2018/1/25/uber-eats-a-necessary-evil-.(accessed April 2 2018).

Roh, T.H. (2016), “The sharing economy: Business cases of social enterprises using collaborative networks", Procedia Computer Science, Vol. 91, pp. 502-511.

Rustagi, S., King, W.R. and Kirsch, L.J. (2008), "Predictors of formal control usage in IT outsourcing partnerships", Information System Research, Vol. 19 No. 2, pp. 126-143.

Sexton, D. (2009), Value Above Cost: Driving Superior Financial Performance with CVA, the Most Important Metric You've Never Used, Upper Saddle River, NJ, FT Press. 
Shaheen, P., and Cohen, A. (2015), Innovative Mobility Carsharing Outlook. available at http://innovativemobility.org/wp-content/uploads/2015/07/Summer-2015-CarsharingOutlook_Final-1.pdf. (accessed 30 April 2018).

Shostack, G. L. (1984), "Designing Services that Deliver", Harvard Business Review, Vol. 62, No. 1, pp 133-139.

Solaimani, S., Bouwman, H. and Itälä, T. (2015), "Networked enterprise business model alignment: A case study on smart living”, Information Systems Frontiers, Vol. 17 No. 4, pp. 871-887.

Subramony, M. and Holtom, B.C. (2012), “The long-term influence of service employee attrition on customer outcomes and profits", Journal of Service Research, Vol. 15 No. 4, pp. 460-473.

Subramony, M., Solnet, D., Groth, M., Hartley, N., Kim, P., Yagil, D., et al. (2018), "Service work in 2050: A work ecosystems perspective", Journal of Service Management, forthcoming.

Stewart, N., and Ferré-Sadurní, L. (2018), "Another taxi driver in debt takes his life. That's 5 in 5 months.", available at: https://www.nytimes.com/2018/05/27/nyregion/taxi-driver-suicidenyc.html (accessed 29 June 2018).

Teece, D.J. (2010), “Business Models, Business Strategy and Innovation”, Long Range Planning, Vol. 43 No. 2, pp. 172-194.

Teubner, T., Dann, D. and Hawlitschek, F. (2017), "Price determinants on AirBnB: How reputation pays off in the sharing economy", Journal of Self-Governance and Management Economics, Vol. 5 No. 4, pp. 53-80.

Treacy, M. and Wiersema, F. (1993), "Customer intimacy and other value disciplines", Harvard Business Review, Vol. 71 No.1, pp. 84-93. 
Tung, W.-F. and Jordann, G. (2017), “Crowdsourcing social network service for social enterprise innovation", Information Systems Frontiers, Vol. 19 No. 6, pp. 1311-1327.

Vafeas, M., Hughes, T., and Hilton, T. (2016), "Antecedents to value diminution: A dyadic perspective", Marketing Theory, Vol. 16 No.4, pp. 469-491.

Van Vaerenbergh, Y. and Orsingher, C. (2016), "Service recovery: An integrative framework and research agenda", Academy of Management Perspectives, Vol. 30 No. 3, pp. 328-346.

Weber, T.A. (2014), "Intermediation in a sharing economy: Insurance, moral hazard, and rent extraction”, Journal of Management Information Systems, Vol. 31 No. 3, pp. 35-71.

Weinstein, B. (2017), "Three industries that should rate customers like Uber does", Forbes, July 12, https://www.forbes.com/sites/bruceweinstein/2017/07/12/three-industries-that-shouldrate-customers-like-uber-does/\#1aeeb5241bdd (accessed 1 May 2018).

Williamson, Oliver E. (1981), “The economics of organizations: The transaction cost approach”, The American Journal of Sociology, Vol. 87 No. 3, pp. 548-577.

Wilson, Charles (2008): “Adverse Selection”, The New Palgrave Dictionary of Economics, 2nd ed.

World Economic Forum. (2018), “Insight Report: Towards A Reskilling Revolution: A Future of Jobs For All", available at:

http://www3.weforum.org/docs/WEF_FOW_Reskilling_Revolution.pdf (accessed 29 May 2018).

Yang, S., Song, Y., Chen, S. and Xia, X. (2017), "Why are customers loyal in sharing-economy services? A relational benefits perspective", Journal of Services Marketing, Vol. 31 No.1, pp. 48-62. 
Zelizer, V. (2007), "The Purchase of Criticism", Sociological Forum, Vol. 22 No. 4, pp. 612617.

Zervas, G., Proserpio, D. and Byers, J. (2017), "The rise of the sharing economy: Estimating the impact of Airbnb on the hotel industry", Journal of Marketing Research, Vol. 54 No. 5, pp. 687-705. 
Table I. A comparison between the M-model and the T-Model

\begin{tabular}{|c|c|c|}
\hline & M-Model & T-Model \\
\hline Basic philosophy & $\begin{array}{l}\text { Dyadic. Selling products or } \\
\text { services to a buyer. }\end{array}$ & $\begin{array}{l}\text { Triadic. Facilitating the exchange of } \\
\text { assets or time between buyers and } \\
\text { suppliers. Sharing products or time as a } \\
\text { service. }\end{array}$ \\
\hline $\begin{array}{l}\text { Organizational } \\
\text { structure and culture }\end{array}$ & $\begin{array}{l}\text { Hierarchy. Fixed. Vertical } \\
\text { top-down communication between } \\
\text { actors. Fixed (single) location. } \\
\text { Advanced regulations. } \\
\text { Low agile culture. Low scalability. }\end{array}$ & $\begin{array}{l}\text { Network. Flexible. Horizontal } \\
\text { communication between actors. } \\
\text { Distributed to many locations. } \\
\text { Emerging regulations. } \\
\text { Highly agile culture. High scalability. }\end{array}$ \\
\hline Costs & $\begin{array}{l}\text { Costs of tangible assets, financial } \\
\text { costs and transaction } \\
\text { costs are high. }\end{array}$ & $\begin{array}{l}\text { Costs of tangible assets, financial costs } \\
\text { and transaction costs are low. }\end{array}$ \\
\hline $\begin{array}{l}\text { Role of data and } \\
\text { performance } \\
\text { measures }\end{array}$ & $\begin{array}{l}\text { Limited use of data. Single actor } \\
\text { (firm) oriented performance } \\
\text { metrics. }\end{array}$ & $\begin{array}{l}\text { Extensive use of data. Multi-actor } \\
\text { (supplier, buyer and platform) oriented } \\
\text { use of performance metrics. }\end{array}$ \\
\hline $\begin{array}{l}\text { Revenue model and } \\
\text { selling approach }\end{array}$ & $\begin{array}{l}\text { Focus on sales and indirect selling } \\
\text { approach. }\end{array}$ & $\begin{array}{l}\text { Focus on transaction fees, advertising and } \\
\text { subscription. Direct selling approach. }\end{array}$ \\
\hline $\begin{array}{l}\text { Employment and co- } \\
\text { creation }\end{array}$ & $\begin{array}{l}\text { Insourced employees with clear } \\
\text { roles. Co-creation focus on } \\
\text { interaction between firm and buyer. }\end{array}$ & $\begin{array}{l}\text { Outsourced employees with blurry roles. } \\
\text { Co-creation focus on interaction between } \\
\text { supplier, buyer and platform. }\end{array}$ \\
\hline
\end{tabular}


Table II. List of Potential Topics for Future Research on T-Models

\section{Value How can platforms create competitive advantage?}

creation How can suppliers make themselves more attractive than traditional competitors? How can they make themselves more attractive than customer ownership (for assets) or customers performing tasks themselves (for labor)?

\section{What is the optimal branding strategy for T-models?}

To what extent should organizations stress utilitarian or environmental benefits? If T-model organizations consolidate, should they adopt a house of brands (e.g. Unilever) or a brand house (e.g. Virgin) strategy?

How can organizations foster and maintain customer loyalty within a T-model?

How can organizations secure sufficient service quality so customers do not defect? Do customers form loyalty toward suppliers? How can organizations make sure such loyalty does not lead customers to bypass the platform in order to further reduce transaction costs?

\section{How can organizations optimally match customers and suppliers?}

How can organizations use data to optimize operations, predict both demand and supply, and suggest innovations based on customer data? Which algorithms are necessary to optimize the match between customers and suppliers? How can organizations use data to evaluate in real-time supplier and customer performance?

\section{How to recruit and select suppliers?}

Can the organization impose strict rules to recruitment and selection of suppliers without jeopardizing a steady supply? What can we learn from employer branding literature? How can organizations generate sufficient highquality supply? How do the (at this point in time) unfavorable worker conditions affect supply of labor in the future?

\section{How to manage risk within the T-model?}

Which risks and other barriers do the three parties within the T-model face? What is their relative importance and how does this change over time? What is the optimal distribution of risk between the three parties? How can organizations alleviate these risks and barriers? What is the best approach to governance: Trust or control? How do customers react to being rated themselves? How does this change consumer behavior?

How should organizations manage service failures within the T-model?

How can organizations deal with service failures given the triadic nature of exchange? Who do customers blame? Who should take the lead in recovery? And what does it take to recover a service failure caused by a supplier?

Value How can societies prepare themselves for a $T$-model future?

destruction Given that self-employment will increase, how can societies optimally prepare youngsters for a more uncertain future? How can governments, that oftentimes create different taxation rates and social security conditions for self-employed people, adapt to such a future?

(How) should a market dominated by T-models be regulated?

Should the government intervene? What is the optimal level of government regulation? How can governments regulate without blocking innovation? How can we adapt legislation which is typically tailored to the M-model?

What are long-term consequences of the shift toward T-models?

Do T-models generate a more efficient use of natural resources, as proclaimed in the sharing economy? When do T-models strengthen a sense of community through trust, reciprocity, cooperation, and decentralization? How can we motivate organizations to go beyond short-term economic goals and use the models for the longer term good of societies?

Can the T-model benefit organizations active in emerging countries?

What are the opportunities in emerging economies for platform operators in the sharing economy, such as in the tourism sector? Can the sharing economy form a way to overcome or avoid corruption or disproportional earnings in some sectors? 
Figure 1: Value creation processes in the T-model

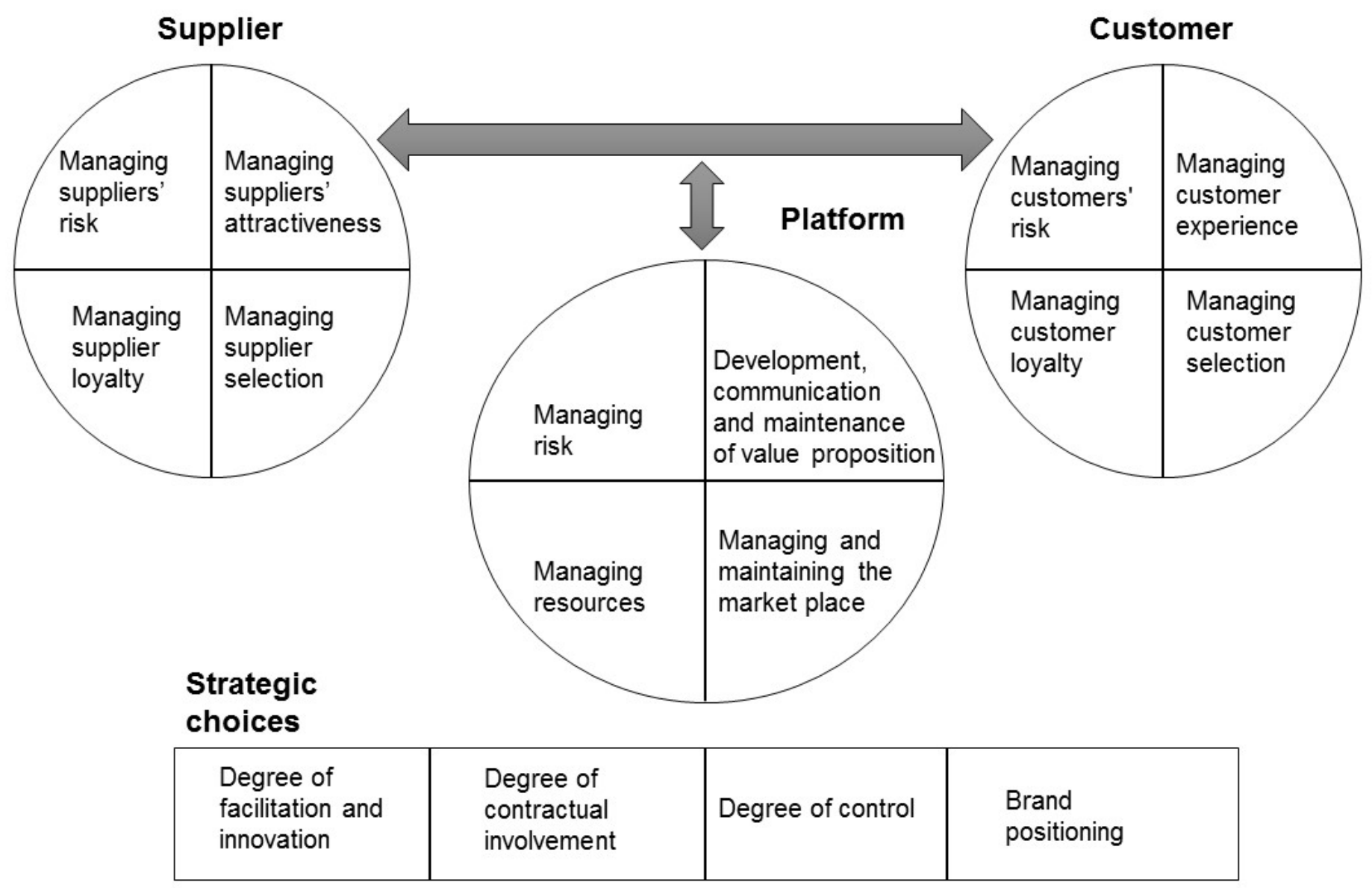


Figure 2: The T-model business canvas (adapted from Osterwaler and Pigneur, 2010)

\begin{tabular}{|c|c|c|c|c|c|}
\hline \multicolumn{2}{|c|}{ PLATFORM (FOCAL) COMPANY } & \multicolumn{2}{|c|}{ CUSTOMERS AND SUPPLIERS } & \multicolumn{2}{|r|}{ DARK SIDE } \\
\hline $\begin{array}{l}\text { Platform risks } \\
\text { - Customer } \\
\text { opportunism } \\
\text { - Customer } \\
\text { dissatisfaction \& } \\
\text { churn } \\
\text { - Supplier } \\
\text { - opportunism } \\
\text { displier } \\
\text { churn } \\
\text { - Brand dilution }\end{array}$ & $\begin{array}{l}\text { Key platform } \\
\text { activities } \\
\text { - Managing supplier } \\
\text { - attractiveness } \\
\text { Designing, communicating \& } \\
\text { - Maintaining value propositions } \\
\text { Managing \& maintaining the } \\
\text { - Manket place } \\
\text { - Managing resources } \\
\text { rating and review systems supplier } \\
\text { - Upsaling or downscaling } \\
\text { - Insurances }\end{array}$ & $\begin{array}{l}\text { Value propositions } \\
\text { to customers } \\
\text {. Customer value (benefits) } \\
\text { - Customer journey } \\
\text { - } 7 \text { P modomer experience }\end{array}$ & $\begin{array}{l}\text { Customer } \\
\text { relationships } \\
\text { - Customer engagement } \\
\text { - Customer loyalty } \\
\text { - Customer lifetime value } \\
\text { - Customer engagement } \\
\text { value }\end{array}$ & $\begin{array}{l}\text { Customer } \\
\text { segments and } \\
\text { selection } \\
\text { - Identifying, selecting and } \\
\text { keeping the right customers } \\
\text { - Eliminating bad customers }\end{array}$ & $\begin{array}{l}\text { Customer risks } \\
\text { - Supplier opportunism } \\
\text { - Supplier bad behavior } \\
\text { - Product or service failure } \\
\text { - Heterogeneity in quality }\end{array}$ \\
\hline $\begin{array}{l}\text { Key } \\
\text { stakeholders } \\
\text { - Customers } \\
\text {. Suppliers } \\
\text { - Banks } \\
\text { - Technology } \\
\text { providers } \\
\text { - Partners } \\
\text { - Society }\end{array}$ & $\begin{array}{l}\text { Key platform } \\
\text { resources } \\
\text { - Technology } \\
\text { - Knowledge } \\
\text { - Brand } \\
\text { - Assets } \\
\text { - Labour }\end{array}$ & $\begin{array}{l}\text { Value propositions } \\
\text { to suppliers } \\
\text {. Supplier value (profits) } \\
\text {. Supplier experience } \\
\text { - } 7 \text { P model }\end{array}$ & $\begin{array}{l}\text { Supplier } \\
\text { relationships } \\
\text { - Supplier involvement } \\
\text { - Supplier loyalty } \\
\text { - Supplier compliance } \\
\text { - Supplier metrics }\end{array}$ & $\begin{array}{l}\text { Supplier } \\
\text { segments and } \\
\text { selection } \\
\text { - Identifying, selecting and } \\
\text { keeping the right suppliers } \\
\text { - Delisting bad suppliers }\end{array}$ & $\begin{array}{l}\text { Supplier risks } \\
\text { - Damage to assets } \\
\text { - Abuse of labour } \\
\text { - Customer opportunism } \\
\text { Customer bad behaviour }\end{array}$ \\
\hline \multicolumn{5}{|c|}{ Financial flows \& profits } & $\begin{array}{l}\text { Societal risks } \\
\text { - Unemployment } \\
\text { - Lawlessness } \\
\text { - Value destruction }\end{array}$ \\
\hline
\end{tabular}

